(C) 2021 Katedra Białorutenistyki UW. Wydanie w otwartym dostępie na licencji CC BY-NC-ND (https://creativecommons.org/licenses/by-nc-nd/4.0/deed.pl)

ACTA ALBARUTHENICA 21: 2021

DOI: 10.32612/uw.18988091.2021.21.pp.81-95

\author{
Angela Espinosa Ruiz \\ Uniwersytet Warszawski / University of Warsaw \\ ORCID: https://orcid.org/0000-0002-5434-8403 \\ e-mail: a.espinosa-ruiz@uw.edu.pl
}

\title{
Барбара Квапіш: лодзінская экзафаністка з падляскім сэрцам
}

Barbara Kwapisz: a Łódź exophonist with a Podlasie heart

Barbara Kwapisz: łódzka egzofonistka o podlaskim sercu

2 'ява шматмоўнай творчасці надзвычай характэрная літаратуры Беларусі: гісторыя краю спрыяла стварэнню мастацкіх тэкстаў на розных мовах. У часы Вялікага Княства Літоўскага Мікола Гусоўскі тварыў на латыні, Андрэй Рымша выкарыстоўваў лацінскую, польскую і старабеларускую мовы ў сваіх вершах і хроніках. Моўнае пытанне працягвала мець асаблівую вагу цягам стагоддзяў: пра гэта сведчаць і забарона беларускамоўнага друку ў XIX стагоддзі, і паралельнае развіццё ананімнай літаратурнай творчасці па-беларуску, і з'яўленне газетаў “Наша Доля” ды “Наша Ніва”, і асэнсаваны выбар мовы творчасці Янкам Купалам, Якубам Коласам ці Максімам Багдановічам. Застаецца яно актуальным і сёння, калі шматлікія беларускія і падляшскія літаратары працягваюць свядомы шлях вяртання да беларускага Слова.

Панятак экзафаніi, у сваю чаргу, паўстаў у літаратуразнаўчым полі адносна нядаўна: ідэю ўпершыню апісалі С’юзан Арндт, Дзірк Нагушэўскі і Роберт Стокхамер у сваёй манаграфіі Экзафанія: розныя мовы (цу) літаратуры [гл.: Susan, Naguschewski, Stockhammer 2007]. Слова “экзафанія”, інтэрпрэтавана як літаратурная з'ява [Wright 2010: 22] або літаратурны жанр [McMillin 2017: 87], ужываецца для апісання сітуацыі, калі “пісьменнік або пісьменніца працуе на мове, адрознай ад сваёй роднай" [Wright 2008: 27].

Варта звярнуць асаблівую ўвагу на тое, што такое разуменне паўстала ў кантэксце нямецкамоўнай літаратуры, і хутка распаўсюдзілася ў вывучэнні літаратур на галоўных еўрапейскіх мовах (англійскай, французскай, іспанскай), стала карыстацца попытам у галіне посткала- 
ніяльных даследаванняў. Развіццю творчасці іншамоўных літаратараў спрыяюць, у гэтым выпадку, не толькі геапалітычныя, гістарычныя і сацыяльныя абставіны, а таксама і памер літаратурнага рынку на самых папулярных мовах Еўропы, і міграцыйныя тэндэнцыі, і лічба вучняў дадзеных моў як замежных.

Яшчэ адно пытанне патрабуе нашай увагі ў стасаванні экзафаніі да беларускіх рэалій: разуменне экзафанічнай літаратуры цесна звязана з разуменнем роднай (або, у пэўных выпадках, першай) мовы пісьменніка. Само гэтае паняцце - "родная мова" - часта з'яўляецца ў цэнтры навуковых, лінгвістычных і сацыялагічных дэбатаў, бо яго інтэрпрэтацыя залежыць ад геаграфічных, гістарычных, і нават індывідуальных эмацыянальных і афектыўных фактараў.

Французская філалагіня Луіза Дабэн грунтоўна прааналізавала парасонавы тэрмін "матчына мова"1 у кнізе Сацыялінгвістычныя арыенціры для выкладання моў: шматмоўныя сітуацыі (1994). У якасці высновы свайго даследавання, яна вызначае чатыры акрэсленні таго, што можна лічыць роднай мовы чалавека, а менавіта:

1. Мова маці, гэта значыць, мова, якой карыстаецца (карысталася) маці чалавека, згодна з строга этымалагічным падыходам.

2. Мова, якою чалавек авалодаў першай, з увагай на храналагічны парадак авалодання мовамі прамоўцам.

3. Мова, якою чалавек валодае найлепш, асацыюецца з суб’ектыўнай ацэнкай прамоўцы датычна ўзроўню валодання адной мовай над іншымі вядомымі яму мовамі.

4. Мова, якою чалавек авалодаў натуральным шляхам, гэта значыць, шляхам непасрэднага ўзаемадзеяння 3 навакольным светам, без (значнага) педагагічнага ўмяшання і з мінімальнымі свядомымі стараннямі [Dabène 1994: 21].

Аднак існуе і іншы падыход да паняцця "родная мова", які захоўвае сваю актуальнасць у кантэксце беларускамоўнай літаратуры, як у Белаpусі, так і ў Польшчы: "родная мова - гэта мова нацыі, мова продкаў, якая злучае чалавека з яго народам, з папярэднімі пакаленнямі, ix духоўным светам" [Чахоўская 2018: 195].

Гэтае акрэсленне звязвае роднасць мовы не з непасрэднымі паказчыкамі валодання ёю або чарговасцю яе вывучэння, а з эмацыянальнымі, культурнымі і гістарычнымі фактарамі, што дазваляе нам вызначыць мяжу паміж дзвюма прынцыпова адрознымі катэгорыямі беларускіх літаратараў: з аднаго боку, этнічныя беларусы і беларускі, якія паходзяць з рускамоўных або польскамоўных сем'яў, але ўдасканальваюць сваю беларускую мову ў падлеткавым ці дарослым веку, і выбіраюць менавіта яе як мову творчасці. Да гэтай катэгорыі адносім

1 Анг. "mother tongue". 
таксама грамадзян Беларусі з іншым этнічным паходжаннем, якія ствараюць літаратуру па-беларуску. 3 іншага ж боку ўплываюць на развіццё літаратуры на беларускай мове ўласна экзафаністы - грамадзяне іншых краін без сувязяў з беларускай дзяржавай і нацыяй, якія вывучаюць беларускую мову як замежную і пачынаюць пісаць на ёй літаратурныя творы.

Да другой групы належаць такія творцы, як паэт Аляксей Арцёмаў з Расіі (Тула, 1991 г. нар.), грамадзянін Кітая Ван Шывей (Гуанчжоу, 1987 г.), вядомы пад літаратурным псеўданімам Яша Ван, або іспанка Анхела Эспіноса Руіс (Малага, 1993 г.). Такія выпадкі, адносна рэдкія для беларускага літаратурнага працэсу, становяцца вядомыя дзякуючы глабалізацыі камунікацый, сацыяльным сеткам і хуткасці распаўсюду інфармацыі ў нашую эпоху. Мэта гэтага артыкула - накіраваць належную навуковую і чытацкую ўвагу на паэтку старэйшага пакалення, чый лёс звязаў яе прафесійную дзейнасць з Белавежай, а творчасць - з беларускаю моваю.

Барбара Квапіш нарадзілася 7 ліпеня 1949 года ў Лодзі, у тыповай польскай сям'і. Там будучая паэтка закончыла пачатковую і сярэднюю школу, пасля чаго атрымала вышэйшую адукацыю ў галіне педагогікі ў Гданьску і Ольштыне. Знакавым у яе творчым лёсе стаў 1976 год, калі Квапіш пераехала ў Белавежу і распачала настаўніцкую дзейнасць у мясцовай пачатковай школе. Там здарыўся яе першы кантакт з беларускай этнічнай меншасцю ў Польшчы: Б. Квапіш змагла пазнаёміцца з беларускай мовай, культурай, літаратурай і бачаннем свету, якія яе, як даводзяць яе пазнейшыя літаратурныя публікацыі, зачаравалі.

Пры вывучэнні праблемы выбару пісаць па-беларуску, навукоўцы і крытыкі задаюцца пытаннем: што паслужыла натхненнем ці матывацыяй пераходу, стараюцца зразумець, што спрыяе такому працэсу, і як ён рэалізуецца. Вось што, напрыклад, напісаў Міхась Стральцоў пра класіка новай беларускай літаратуры Максіма Багдановіча:

\footnotetext{
Упершыню на радзіму ён прыязджае ў дваццаць год. Дваццаць год - гэта многа толькі для Багдановіча, бо ён ужо вядомы беларускі паэт. Але вось якая парадаксальная і адначасова зварушлівая рыса: беларускі паэт амаль не ўмее гаварыць па-беларуску! Нібы іншаземец, ён просіць кожнага, з кім размаўляе, папраўляць яго гаворку. I ў той жа час ён заклапочаны беларускімі праблемамі, як мала хто з “цэнтрыстаў”, людзей, якія займаліся грамадскай ці літаратурнай дзейнасцю непасрэдна “на месцах [Стральцоў 1969: 13].
}

Гісторыя Б. Квапіш не такая трагічная і легендарная, як лёс М. Багдановіча, але яе можна лічыць не менш загадкавай: калі М. Багдановіч захоўваў моцную этнічную і ідэалагічную сувязь з Беларуссю і адраджэннем беларушчыны, дык Б. Квапіш была этнічнай полькай 
з Лодзі, якая ледзь не выпадкова апынулася ў беларускім асяроддзі ўжо ў дарослым веку. Пераезд у Падляшскае ваяводства моцна паўплываў на свядомасць і ідэнтычнасць Б. Квапіш. Як тлумачыць праф. Аляксандар Баршчэўскі,

папаўшы ў беларускую псіхалагічную, моўную і культурную стыхію, яна паддала сваю душу і свядомасць працэсу павольнага абеларушвання. Такое высакароднае стаўленне даецца толькі тым адважным і арыгінальным асобам, якія лічаць, што эмацыянальнае і духоўнае далучэнне да мясцовага люду з'яўляецца не здрадніцтвам у адносінах да сваёй уласнай нацыі, а толькі формай пашырэння і ўзбагачэння сваёй душы [Баршчэўскі 2001: 160-161].

Сама паэтка выказалася пра сваё асабістае моўнае пытанне ў кароткай нататцы, якая друкавалася разам з яе дэбютным вершам у тыднёвіку “Ніва” 7 лістапада 1976 года:

Вершы пачала пісаць у мінулым годзе, і пераважна на польскай мове. Беларускую, на жаль, ведаю яшчэ слаба, але мяне захапляе яе прыгажосць. Паказваецца гэта мне звонкай, сочнай. Чутна ў ёй душа народу. Мне хочацца дакладна пазнаць спосаб мышлення і спецыфіку жыцця тутэйшых жыхароў, таму безупынна буду пазнаваць беларускую мову і буду штораз адважней пісаць на ёй вершы [Квапіш 1976, № 45: 3].

Варта заўважыць, што маладая паэтка пачала сваю літаратурную працу за год перад з'яўленнем першых беларускамоўных вершаў у друку, з чаго вынікае, што менавіта беларуская мова і культура Падляшша маглі стаць каталізатарам не толькі новага кірунку ў творчасці Б. Квапіш, але і пачатку яе літаратурнай дзейнасці ў цэлым.

Нягледзячы на словы паэткі аб тым, што яе валоданне беларускай мовай было "слабае" на момант літаратурнага дэбюту, мы заўважылі ў першым надрукаваным творы Б. Квапіш прыкметы значнага таленту і выдатнай моўнай інтуіцыі:

Нічога я сёння не напісала ні ў блакітнай цішыні раніцы, ні ў душны сонцам поўдзень, ні ў змярканні, туманам скупаным.

Сёння муза паэзіі вытанчаным сваім светам Улавіць мяне не хацела

I толькі здалёк, лёгкая, стаяла.

Бо ў цішыні раніцы, у душны поўдзень, I ў змярканні, знікаючым у ночы акіянах, У кожнай маёй мыслі, пачуцці і празе,

У боязі няпэўнасці, прыплыве надзеі - цябе прыкмячала [Квапіш 1976, 45: 3] 
У першую чаргу нашу ўвагу звярнула на сябе сінестэзія, якая з'яўляецца ў другім радку, “ў блакітнай цішыні раніцы”: блакітны колер асацыюецца з ясным, ранішнім небам позняй вясны або лета, пра якія нагадвае верш сваёй спакойнай атмасферай (“у душны поўдзень", “у ночы акіянах"). У той жа час, блакітныя танальнасці акрэсліваюць і цішыню, сугучную з роздумам паэтычнай гераіні.

Гэтаксама вартыя ўвагі алітарацыі, якія ўпрыгожваюць вольныя радкі верлібра (“сваім светам”, “здалёк, лёгкая”, “знікаючым у ночы”), чыя форма паказвае ўплыў заходніх паэтычных тэндэнцый на творчую свядомасць паэткі.

Галоўным адкрыццём верша, на нашу думку, ёсць пераход ад абстрактнага тэксту, напісанага ад першай асобы, з пункту гледжання гераіні/аўтаркі, да асабістага прысвячэння, калі ў апошнім радку ўпершыню ўжываецца займеннік другой асобы (“цябе прыкмячала"). Гэтае слова і дае чытачам ключ да разгадкі паэтычнай таямніцы: аб’ект хваляванняў лірычнай гераіні не хаваецца ў складанасцях пісьменніцкай дзейнасці або ў капрызах муз, а менавіта ў другім чалавеку, у гэтым “ты”, да якога яна звяртаецца напрыканцы верша.

Наступная публікацыя Б. Квапіш у “Ніве” з'явілася праз месяц пасля першай, 5 снежня 1976 г. Гэта адзіны выяўлены намі верш яе аўтарства, які мае тытул, да таго ж - моцна эратычны, Прага незнікаючая:

\section{Прага незнікаючая}

У ночы дажджом шумячай, Вочы твае толькі блакітнелі. Зрэнкі нашыя, затапляючыся ў сабе, Ці... супольны свет з двух асобных будавалі? Ці выкрэслівалі адзіны шлях?

Не было тваіх, ні маіх - ног ні рук, Усмешак ні жэстаў.

3 плачучым увесь час небам і зямлёй Паказвалася, што вочы губляюцца ў небыццё.

I нішто не было важнае. Бо нічога не было. Толькі твае вочы, заўсёды ўглядаючыеся, Праз якія - як вароты - гэта вельмі жадала б Увайсці і... астацца ў табе.

[Квапіш 1976, № 49: 3]

Пасля ўважлівага прачытання гэтага твора можам сцвердзіць, што маладая паэтка выканала сваё абяцанне “штораз адважней” пісаць вершы на беларускай мове. Кідаецца ў вочы кантраст з першым, дэбютным вершам Б. Квапіш: калі той тэкст закранаў пытанні літаратурнай творчасці, засяроджваўся ў атмасферы агульнай меланхоліі, і толькі у апошнім радку выяўлялася прычыну тугі лірычнай гераіні, прыхава- 
най у таемным “ты”, дык у вершы Прага незнікаючая яна з пачатку дзеліцца з чытачамі рамантычным, нават сэксуальным светам і жарснай атмасферай: “У ночы дажджом шумячай / вочы твае толькі блакітнелі". Лірычная гераіня звяртаецца да свайго “ты” ўжо ад другога радка, і выкарыстоўвае прыналежны займеннік “нашыя" (“Зрэнкі нашыя”) ў трэцім радку, чым пацвярджаецца любоўная сувязь двух лірычных герояў.

Мы пазналі тут і некаторыя элементы, якія працягваюць стылёвыя і эстэтычныя пачынанні першага твора аўтаркі, напрыклад, блакітны колер у адносінах да каханага, які застаецца чыстым і ясным сярод дажджу і начной цемры ("вочы твае толькі блакітнелі"), а таксама філасофскія тэндэнцыі паэткі: “супольны свет з двух асобных будавалі?”, "вочы губляюцца ў небыццё”, "I нішто не было важнае. Бо нічога не было".

Не можам не звярнуць увагі на моўны бок другога беларускага твора Б. Квапіш. Актуальнасць гэтага пытання заўжды высокая пры вывучэнні экзафанічнай творчасці, бо літаратары, якія выбіраюць няродную мову як творчую, павінныя знайсці ўласны падыход да новай знакавай, эстэтычнай і граматычнай сістэмы. 3 нашага аналізу верша Прага незнікаючая вынікае выснова аб тым, што Б. Квапіш смела займаецца пошукам на дадзеным этапе: мы заўважылі, напрыклад, ужыванне дзеепрыметнікаў, якія часта сустракаюцца ў польскай і рускай мовах, але не ўласцівыя беларускай натуральнай гаворцы: "шумячай”, “затапляючыся”, “плачучым”, “ўглядаючыеся”. Таксама звярнулі ўвагу на выбар дзеяслова ў апошнім радку, "астацца ў табе”, замест “застацца". Літаратурная беларуская мова прызнае абодва варыянты слова, аднак форма "застацца" дазволіла б пазбегнуць чаргавання галосных гукаў ("i-астацца"), і супадае з сучаснай польскай формай “zostać”. Аднак на Б. Квапіш магла аказаць свой уплыў іншая польская дзеяслоўная форма, архаічная "ostać się", якая выкарыстоўвае рэфлексіўны займеннік гэтак жа, як і беларускі дзеяслоў “астацца”.

На нашу думку, у сваім другім вершы паэтка паказвае, што яна нарэшце гатовая ісці на пэўную рызыку дзеля экспрэсіўнасці, моцы і арыгінальнасці твора, і не можам адмаўляць, што, нягледзячы на моўныя недакладнасці або хібы, аўтарцы ўдалося ўвесці ў беларускую паэзію шчыры і адкрыты, але ў той жа час інтэлектуальны і элегантны эратызм, які ўзбагаціў сваёй адвагаю тагачасны падляшскі літаратурны працэс.

Б. Квапіш не перастае здзіўляць чытацкую публіку і ў сваёй трэцяй публікацы, 6 лютага 1977 г. Новы верш без загалоўка знаёміць нас з унутранымі экзістэнцыйнымі канфліктамі лірычнай гераіні, чыёй душы цесна ва ўласным целе: 


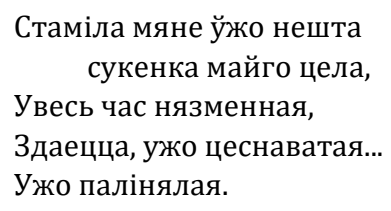

Але калі б я яе зняла,

Ці душа мая мяне б захапіла?

змяла

і кінула...

Ці ў зернях гадзінаў штодзённасці шэрай душа цвіла кветкай, ці спапялялася?

[Квапіш 1977, № 6: 3].

Лірычная гераіня не толькі выражае сваю стому і дыскамфорт, а таксама задае сабе важнае пытанне: што здарылася б, калі б яна "зняла, / змяла / і кінула” сукенку свайго цела? У вершы прадстаўляюцца дзве альтэрнатывы: “душа цвіла [б] кветкай, / ці спапялялася?”. Гэта значыць, што цела для Б. Квапіш не толькі абмежаванне духоўнага свету, але і яго абарона, і зняць яго нясе пэўную рызыку - ператварыцца, або вярнуцца, у попел, як дыктуе хрысціянская традыцыя.

Сумесь філасофіі з каханнем працягваецца ў наступным апублікаваным вершы паэткі, 6 сакавіка 1977 г.:

\author{
Калі будзем з "Сонца" піць, \\ К "Сонцу" узрастаць, \\ Сэрца як чашачкі кветак духмяных \\ Для свету раскрываць... \\ Або калі не зможам, \\ Мо не ўмелі... \\ А мо не хацелі браць з "Сонца" \\ I толькі ў матэрыю цела \\ Матэрыю зямлі будзем ператвараць... \\ Што тады? \\ Дзве розныя да выбару маючы дарогі \\ - дзесьці за парогам жыцця - \\ Разыйдземся, ці адным станемся? \\ [Квапіш 1977, № 10: 3].
}

3 аднаго боку, нельга сказаць, што вобразы, якія Б. Квапіш выкарыстоўвае ў гэтых радках, наватарскія: “чашачкі кветак духмяных", якія раскрываюцца перад сонцам, сімвалізуюць закаханыя сэрцы лірычных герояў, а дзве дарогі ў апошняй страфе намякаюць на вечную дылему - заставацца разам або расстацца. Аднак здзіўляе ўключэнне паэткай глыбейшых філасофскіх задумак, якія запазычваюць паняткі з навукі ("I толькі ў матэрыю цела / Матэрыю зямлі будзем ператвараць...") або з фальклору і народнай веры (“за парогам жыцця”, дзе 
парог ператвараецца ў пераходную прастору паміж светам жывых і светам мёртвых).

Аўтарка прыняла цікавае рашэнне датычна трактавання вобразу сонца: слова з'яўляецца тры разы, заўжды пішацца ў двукоссі і з вялікай літарай. 3 першага погляду падаецца, што сонца для Б. Квапіш галоўная крыніца энергіі і любові (“Калі будзем з "Сонца” піць, / К “Сонцу” узрастаць / <..> А мо не хацелі браць з “Сонца”), якая дорыць закаханым жарсць, сілу і жыццё. Аднак выкарыстанне двукосся падымае пытанне пра магчымыя канатацыі вобразу.

Лёгка асацыяваць вобраз сонца ў вершы Б. Квапіш з вершам Słońce тады моцна цэнзураванага пісьменніка, будучага лаўрэата Нобелеўскай прэміі па літаратуры Чэслава Мілаша:

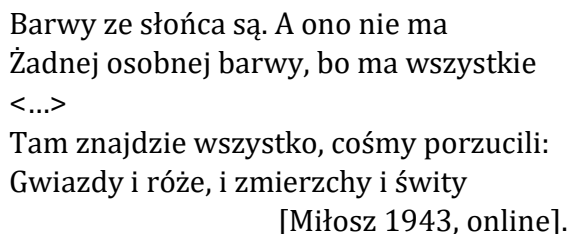

Ч. Мілаш падтрымлівае ў сваім тэксце вобраз сонца-бога, істоты, у якой змяшчаецца “ўсё”. Сувязь між сонцам і Богам пацвярджаецца ў зборніку Ч. Мілаша, які выйшаў у свет у 1974 годзе ў Парыжы, Gdzie wschodzi słońce i kędy zapada. Радок, ужыты ў назве, узяты з перакладу Псалма 113 (112) на польскую мову Францішка Карпінскага: "Gdzie wschodzi słońce i kędy zapada, niechaj świat Bogu chwałę opowiada" [Karpiński 1835: 223].

Аднак цяжка ўявіць, што Ч. Мілаш непасрэдна паўплываў на паэзію маладой Б. Квапіш з улікам працы цэнзурнага апарату таго часу. Пытанне аб тым, ці існаваў супольны ўплыў, або вобраз паходзіць з іншых, уласцівых эпосе, пакідаем адкрытым на далейшыя даследаванні.

Наступныя дзве публікацыі Б. Квапіш у “Ніве” з'явіліся, адпаведна, 1 траўня і 3 ліпеня 1977 года. У іх паэтка паглыбляецца ў класічна-еўрапейскіх каранях свайго лірычнага пачатку, звяртаецца да старагрэцкай міфалогі:

Хацела б я Кальёпе ніць залатую магчы ўхапіць, уплесці яе ў жыццё. Цэлае! Ніццю павучынай, далікатнай аплесціся перад светам і... для свету. Мыслі ў іх раззалаціць, раз'ясніць, сэрца імі заіскрыць, запаліць! I магчы спаліцца ў гэтым агні, выбухным, жыццём пульсуючым, пачуцця крошкі палаючыя, іскрамі жывымі па свеце рассейваючы. 


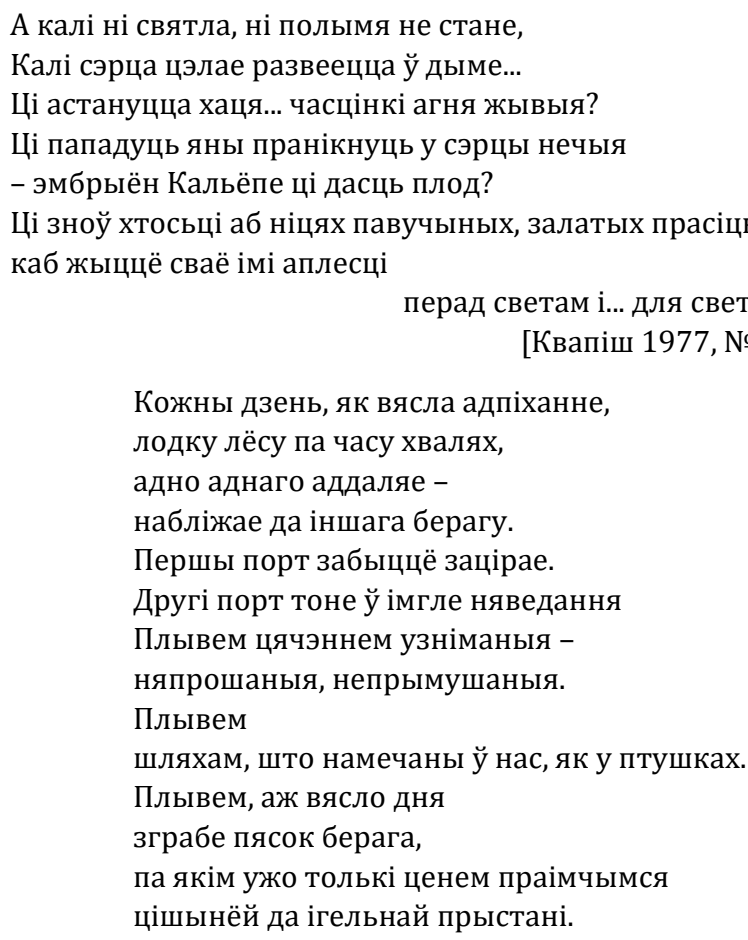

[Квапіш 1977, № 27: 3]

Першы верш сумяшчае вобраз Каліёпы, музы эпікі і красамоўства, і ніткі ("ніць") лёсу. Лірычная гераіня разважвае пра сваё жыццё, які не толькі прыватнае, але і публічнае ў паэзіі (“Ніццю павучынай, далікатнай аплесціся / перад светам і... для свету" / <...> іскрамі жывымі па свеце рассейваючы). Яна задумваецца і аб тым, што застаецца пасля гэтага жыцця, хто працягне творчую справу пасля яго заканчэння: “Ці астануцца хаця... часцінкі агня жывыя?/ <...> эмбрыён Кальёпе ці дасць плод? / Ці зноў хтосьці аб ніцях павучыных, / залатых прасіць яе будзе, / каб жыццё сваё аплесці / перад светам і... для свету?"

Вобразы Каліёпы і ніткі - традыцыйныя, з каранямі ў класічнай міфалогіі і часта выкарыстоўваліся літаратарамі розных эпох і жанраў. Арыгінальнасць твора вынікае з іх сумяшчэння, якім аўтарка вызначае адносіны паміж творчасцю і жыццём у выпадку літаратараў і, агулам, мастакоў.

Другі верш таксама звяртаецца да старагрэцкіх міфалагічных вытокаў, гэтым разам - да вобразу ракі як мяжы паміж светам жывых і светам памерлых (у грэцкай традыцыі гэта рака Лета). Наватарства Б. Квапіш палягае на тым, што яна вылучае некалькі этапаў у гэтым фінальным падарожжы: “Першы порт забыццё зацірае. / Другі порт тоне ў імгле няведання / <...> Плывем, аж вясло дня / зграбе пясок бера- 
га, / па якім ужо толькі ценем праімчымся / цішынёй да ігельнай прыстані". Паэтка паказвае ў гэтым тэксце свой талент у філасофскай лірыцы, глыбіню сваіх думак і перажыванняў: “Кожны дзень, як вясла адпіханне, / лодку лёсу па часу хвалях, / адно аднаго аддаляе -/ набліжае да іншага берагу".

Не абышлося тут без моўных хібаў і памылак друку, хоць яны пераважна малазначныя і могуць быць вытлумачаныя недахопам увагі: "Кальёпе" замест "Каліёпа", “у птушках" замест "у птушак”.

Апошняя публікацыя ў “Ніве”, да якой мы атрымалі доступ, з’явілася ў друку 4 лістапада таго ж года. Гэта адносна доўгі верш, нашмат прасцейшы і больш непасрэдны за папярэднія творы Б. Квапіш:

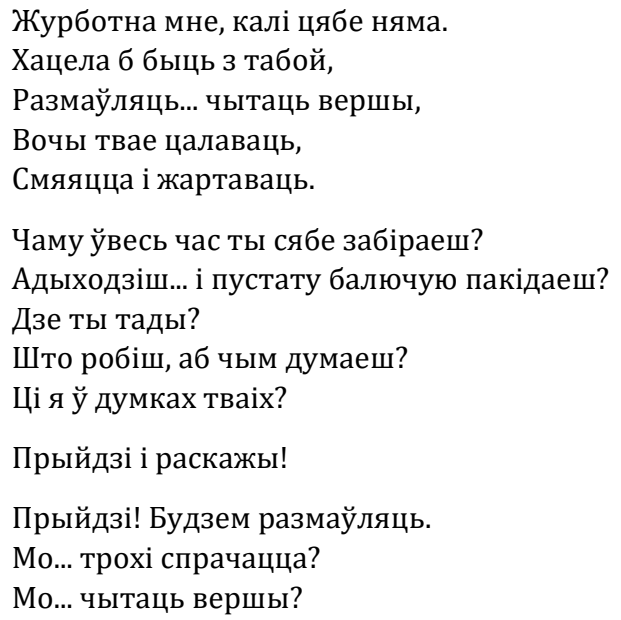

Але напэўна вочы свае будзем цалаваць, Будзем смяяцца, бестурботна жартаваць.

Бо ж толькі ты мне, а я табе

Ружовыя акуляры здолеем надзяваць.

[Квапіш 1979, № 44: 3].

Верш напісаны гутарковым стылем, простымі словамі і думкамі: “Хацела б быць з табой, / Размаўляць... чытаць вершы". Лірычная гераіня зноў звяртаецца да каханага чалавека, да гэтага "ты”, які з'яўляўся ў ранейшых вершах паэткі. Яму лірычная гераіня выказвае і прэтэнзіі пра няшчаснае каханне: "Чаму ўвесь час ты сябе забіраеш? / Адыходзіш... і пустату балючую пакідаеш?” Гэты песімістычны настрой захоўваецца да апошніх радкоў верша, чытаецца між радкоў, сярод наіўных думак пра любоў: “Прыйдзі! Будзем размаўляць. / Мо... трохі спрачацца? / Мо... чытаць вершы?” Напрыканцы лірычная гераіня прызнаецца ў тым, што яе каханне ў пэўнай ступені - самападман і жаданне верыць у лепшае: “Бо ж толькі ты мне, а я табе / Ружовыя акуляры здолеем надзяваць”. 
Мы не змаглі знайсці іншых вершаў Б. Квапіш на старонках тыднёвіка “Ніва", аднак заўважылі яшчэ адну, апошнюю, публікацыю ў літаратурным альманаху “Белавежа" за 1980 год. У ім з'явіліся тры вершы аўтарства Б. Квапіш, якія аналізаваў А. Баршчэўскі ў сваёй кнізе Творцы беларускага літаратурнага руху ў Польшчы 1958-1998.

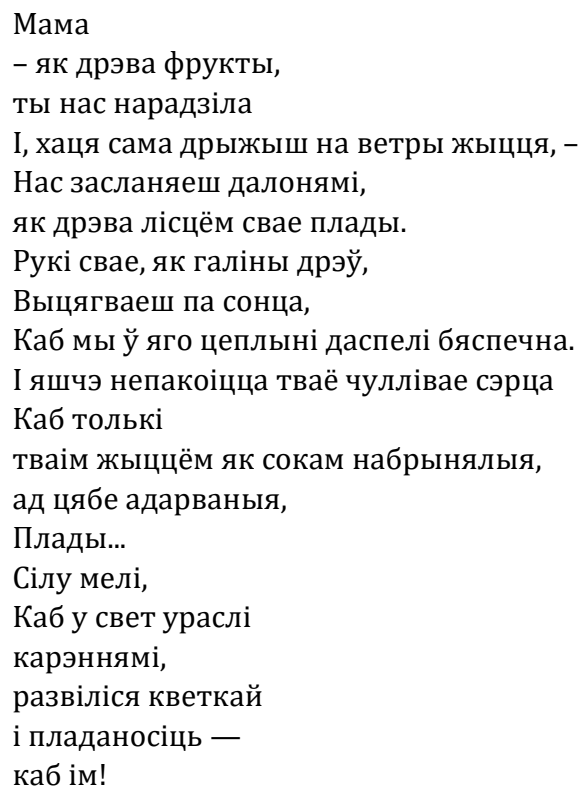

[Квапіш 1980]

Надзвычай пяшчотны і маляўнічы верш, у якім аўтарка апрацоўвае традыцыйны вобраз маці як фруктовага дрэва, якое "<...> нас нарадзіла / <...> Нас засланяеш далонямі, / як дрэва лісцём свае плады”. Вяртаецца да тэксту Б. Квапіш і вобраз сонца, якое дорыць дрэву-маці энергію для выхавання дзетак: “Рукі свае, як галіны дрэў / Выцягваеш па сонца, / Каб мы ў яго цеплыні даспелі бяспечна”. Гэта пазітыўны, светлы верш, у якім выяўляецца і цікавая філасофская або, можа быць, псіхалагічная знаходка - лірычная гераіня прызнае чалавечнасць і слабасць маці, а не бачыць яе як аднабаковую крыніцу любові і моцы для сваіх дзяцей: "I, хаця сама дрыжыш на ветры жыцця", “І яшчэ непакоіцца тваё чуллівае сэрца”.

Другі верш Б. Квапіш у альманаху адлюстроўвае адзін з улюбёных матываў літаратаркі ў паэзіі, зыходзячы з таго, што мы аналізавалі ў гэтым артыкуле. У іх выяўляецца каханне як мімалётны падман:

Твар яшчэ не звянуў

Яшчэ мае сілу прытварацца...

Таму ў вочы мае доўга не глядзі.

Яны - сэрца люстэркам. 


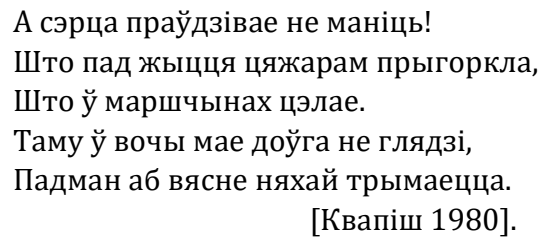

Лірычная гераіня звяртаецца да каханага, папярэджвае яго аб сапраўдных пачуццях: “Таму ў вочы мае доўга не глядзі. / Яны - сэрца люстэркам. / А сэрца праўдзівае не маніць!" У вершы даследуецца таксама страх старэння (і фізічнага, і маральнага), і яе ўплыву на любоўныя жарсці: “[Сэрца] Што пад жыцця цяжарам прыгоркла, / Што ў маршчынах цэлае". Асаблівую паэтычную знаходку мы заўважылі ў апошніх двух радках: “Таму ў вочы мае доўга не глядзі, / Падман аб вясне няхай трымаецца". Вочы, паводле лірычнай гераіні, не ўмеюць хлусіць, таму яна паўтарае сваё папярэджванне і тлумачыць: вясна, як маладосць і любоў, будзе працягвацца, пакуль яны з каханым чалавекам не прымуць горкую праўду.

Апошні вядомы нам верш Б. Квапіш - адлюстраванне філасофскіх роздумаў аўтаркі, у якіх - аптымістычныя высновы:

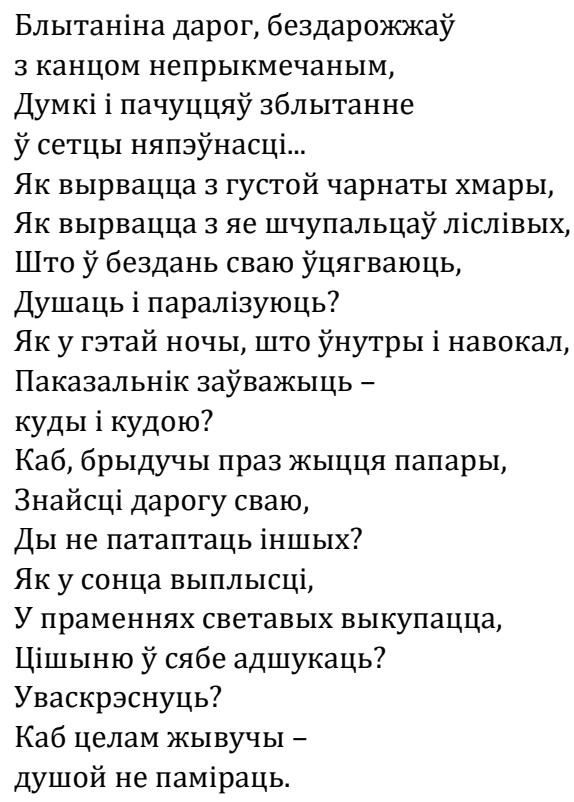

[Квапіш 1980]

Лірычная гераіня задумваецца пра няпэўнасць жыццёвага шляху, задаецца пытаннямі пра адчай і цемру: "Як вырвацца з густой чарнаты хмары, / <...> Што ў бездань сваю ўцягваюць, / Душаць і паралізуюць?” Б. Квапіш не дае ў сваім тэксце гатовых адказаў, а запытвае ў чытачоў, 
“куды і кудою?” Вяртаецца да радкоў паэткі і ўлюбёны вобраз сонца, якое зноў жа выступае як крыніца энергіi і пазітыўных эмоцый: “Як у сонца выплысці, / У праменнях светавых выкупацца". У фінальных радках твора лірычная гераіня ставіць перад сабой пазітыўную мэту, якую можна ўспрымаць як асабістую філасофію або жыццёвае крэда: "Каб целам жывучы - / душой не паміраць".

Дзякуючы аналізу апублікаваных вершаў Б. Квапіш у “Ніве” і “Белавежы” мы пераканаліся ў тым, што яе творчасць заслугоўвае і патрабуе далейшага вывучэння у беларускім літаратуразнаўстве, не толькі з пункту гледжання экзафаніі на беларускай мове, а таксама ў якасці твораў самабытнай паэткі з арыгінальнымі задумамі, вобразамі і стылем. Мы змаглі зразумець пошукі Б. Квапіш сваіх уласных метафараў, гукаспалучэнняў, тэматыкі і праблематыкі - у развіцці яе творчасці з'явіліся такія вобразы, як сонца-крыніца энергіі, блакітны колер як чысціня кахання або ростані дарог з філасофскім падтэкстам. Паляпшалася паралельна і валоданне беларускай мовай Б. Квапіш, лагічная ўзгодненасць яе тэкстаў і ўзровень яе разваг. Асаблівую ўвагу мы звярнулі на трактаванне аўтаркай традыцыйных паэтычных вобразаў (напрыклад, вобразу маці або элементаў старагрэцкага паходжання).

Спадзяемся, што гэты артыкул стане пачаткам шэрагу даследаванняў, якія раскрыюць усе нюансы Б. Квапіш як паэткі і асобы, а таксама яе месца ў гісторыі беларускай літаратуры, а канкрэтна - сярод экзафонных літаратараў, якія паўплывалі і працягваюць уплываць на беларускі літаратурныя працэс.

\section{Бібліяграфія}

Arndt Susan, Dirk Naguschewski, and Robert Stockhammer. 2007. Exophonie: AndersSprachigkeit (in) der Literatur. Berlin: Kulturverlag Kadmos.

Barszczewski Aleksandr. 2001. Tvorcy belaruskaga lìtaraturnaga ruhu ǔ Pol’ščy 19581998. Mìnsk: UP "Tèhnaprynt". [Баршчэўскі Аляксандр. 2001. Творцы беларускага літаратурнага руху ў Польшчы 1958-1998. Мінск: УП "Тэхнапрынт"].

Čahoǔskaâ Taccâna. 2018. Mova ètnasu, mova nacyì, dzâržaǔnaâ mova, rodnâ̂ mova: rolâ rodnaj movy ǔ pracèse stanaǔlennâ asoby ì ǔ razvìccìcyvilìzacyì (192-198). U: Belaruskae slova: tèrmìn ì vobraz: zbornik artykulaǔ pa matèryâlah navukovyh čytannâǔ, prysvečanyh pamâcì prafesara V.P. Krasneâ, g. Mìnsk, 27 snežnâ 2017 g. / BDU, filalagì̌ny fak., kaf. gìstoryì belaruskaj movy; rèdkal.: M.Ì. Svìstunova (adk. rèd.) [ì ìnš.]; pad agul. rèd. M.R. Prygodziča. Mìnsk: BDU [Чахоўская Таццяна. 2018. Мова этнасу, мова нацыі, дзяржаўная мова, родная мова: роля роднай мовы ў працэсе станаўлення асобы і ў развіцці цывілізацыі (192-198). У: Беларускае слова: тэрмін і вобраз: зборнік артыкулаў па матэрыялах навуковых чытанняў, прысвечаных памяці прафесара В.П. Краснея, г. Мінск, 27 снежня 2017 г. / БДУ, філалагічны фак., каф. гісторыі беларускай мовы; рэдкал.: М.І. Свістунова (адк. рэд.) [i інш.] ; пад агул. рэд. М.Р. Прыгодзіча. Мінск: БДУ]. 
Dabène Louise. 1994. Repères sociolinguistiques pour l'enseignement des langues: les situations plurilingues. Paris.

Karpiński Franciszek. 1835. Dzieła Franciszka Karpińskiego. Wydanie nowe Jana Nep: Bobrowicza. Tomik II. Lipsk: Breitkopf et Haertel.

Kwapisz Barbara. 1976. Ničoga â sënnâ ne napìsala... "Nìva” № 45 (1080): 3 [Квапіш Барбара. 1976. Нічога я сёння не напісала... "Ніва" № 45 (1080): 3].

Kwapisz Barbara. 1976. Praga neznikaûčâ̂. "Nìva” № 49 (1084): 3 [Квапіш Барбара. 1976. Прага незнікаючая. “Ніва” № 49 (1084): 3].

Kwapisz Barbara. 1977. Stamila mâne ǔžo nešta... "Nìva” № 6 (1093): 3 [Квапіш Барбара. 1977. Стаміла мяне ўжо нешта... "Ніва” № 6 (1093): 3].

Kwapisz Barbara, 1977. Kalì budzem z "Sonca" pìc'... "Nìva” № 10 (1097): 3 [Квапіш Барбара. 1977. Калі будзем з “Сонца" піць... "Ніва” № 10 (1097): 3].

Kwapisz Barbara. 1977. Hacela b â Kal'ëpe nìc'zalatuû magčy ǔhapìc'. “Nìva” № 18 (1105): 3 [Квапіш Барбара. 1977. Хацела б я Кальёпе ніць залатую магчы ўхапіць. “Ніва” № 18 (1105): 3].

Kwapisz Barbara. 1977. Kožny dzen', âk vâsla adpìhanne... “Nìva” № 27 (1114): 3. [Квапіш Барбара. 1977. Кожны дзень, як вясла адпіханне... "Ніва" № 27 (1114): 3].

Kwapisz Barbara. 1979. Žurbotna mne, kalì câbe nâma... "Nìva” № 44 (1236): 3. [Квапіш Барбара. 1979. Журботна мне, калі иябе няма... “Ніва” № 44 (1236): 3].

Kwapisz Barbara. 1980. Mama... "Belaveža". Belastok: Vydanne galoǔnaga praǔlennâ Belaruskaga gramadska-kul'turnaga tavarystva [Квапіш Барбара. 1980. Мама... “Белавежа". Беласток: выданне Галоўнага праўлення Беларускага грамадска-культурнага таварыства].

McMillin Arnold. 2017. The remarkable Belarusian verse and prose of Ángela Espinosa Ruiz. "New Zealand Slavonic Journal" 51: 87-114.

Miłosz Czesław. 1943. Słońce [online] https://poezja.org/wz/Mi\%C5\%82osz_Czes\%C5\% 82aw/7857/S\%C5\%82o\%C5\%84се [доступ: 20.08.2021].

Stral'coǔ Mìhas'. 1969. Zagadka Bagdanoviča. Mìnsk: Mastackaâ lìtaratura [Стральцоў Міхась. 1969. Загадка Багдановіча. Мінск: Мастацкая літаратура].

Wright Chantal. 2008. Writing in the 'Grey Zone': Exophonic Literature in Contemporary Germany. "German as a foreign language”, № 3: 26-42.

Wright Chantal. 2010. Exophony and literary translation: What it means for the translator when a writer adopts a new language. "Target. International Journal of Translation Studies" № 22.1: 22-39.

ABSTRACT: This article explores the known published lyrical works of Barbara Kwapisz (1949), a Polish-born poet who learnt Belarusian upon moving to Białowieża to work as a teacher and coming into contact with the local Belarusian ethnic minority, their customs and culture. In order to analyse Kwapisz's poetry, we consulted the archive of the weekly magazine "Niva", as well as the 1980 edition of the "Belaveža" literary almanac. We managed to find a total of 11 poems dating from 1976 to 1980 which we analysed from the linguistic and literary point of view. After our study of Barbara Kwapisz's works, we came to the conclusion that her poetry deserves both recognition and scientific attention, since she is both a key representative of the phenomenon of exophony in the Belarusian language and a notable poet.

KEYWORDS: Barbara Kwapisz, exophony, Belarusian language, Belarusian literature in Poland, minority literature, national minority literature. 
STRESZCZENIE: W niniejszym artykule analizujemy znane publikowane utwory liryczne Barbary Kwapisz (1949), urodzonej w Polsce poetki, która po przeprowadzce do Białowieży dla pracy nauczycielskiej zetknęła się z lokalną białoruską mniejszością etniczną, jej obyczajami i kulturą, oraz nauczyła się języka białoruskiego. W celu analizy poezji B. Kwapisza skorzystaliśmy z archiwum tygodnika „Niva” oraz wydania almanachu literackiego „Belaveža” 1980 roku. Udało nam się znaleźć łącznie 11 wierszy z lat 1976-1980, które przeanalizowaliśmy pod względem językowym i literackim. Po przestudiowaniu twórczości B. Kwapisz doszliśmy do wniosku, że jej poezja zasługuje zarówno na uznanie, jak i na uwagę naukową, ponieważ jest ona zarówno kluczowym przedstawicielem zjawiska egzofonii w języku białoruskim, jak i wybitną poetką.

SŁOWA KLUCZOWE: Barbara Kwapisz, egzofonia, język białoruski, literatura białoruska w Polsce, literatura mniejszości narodowych.

РЭЗЮмЭ: У артыкуле даследуюцца вядомыя апублікаваныя лірычныя творы Барбары Квапіш (1949г. н.), паэткі польскага паходжання, якая вывучыла беларускую мову пасля таго, як пераехала ў Белавежу працаваць настаўніцай і ўступіла ў кантакт з мясцовай беларускай этнічнай меншасцю, яе звычаямі і культурай. Для таго, каб прааналізаваць паэзію Б. Квапіш, мы звярнуліся да штотыднёвіка "Ніва", а таксама да літаратурнага альманаха "Белавежа" за 1980 год. Нам удалося выявіць у агульнай колькасці 11 вершаў за 19761980 гг., якія мы прааналізавалі з моўнага і літаратурнага пункту гледжання. Пасля вывучэння твораў Б. Квапіш мы прыйшлі да высновы, што яе паэзія заслугоўвае як прызнання, так і навуковай увагі, бо яна адначасова ёсць ключавою прадстаўнічкай з'явы экзафаніі на беларускай мове і выдатнай паэткай.

ключАВыя словы: Барбара Квапіш, экзафанія, беларуская мова, беларуская літаратура ў Польшчы, літаратура нацыянальных меншасцей.

Data przesłania artykułu: 22.08 .2021 Data akceptacji artykułu: 20.11.2021

\section{ABOUT THE AUTHOR / O AUTORZE}

Angela Espinosa Ruiz / Анхела Эспіноса Pyic - Polska, Uniwersytet Warszawski, Katedra Białorutenistyki; dr.; specjalność naukowa: literaturoznawstwo białoruskie; zainteresowania naukowe: literaturoznawstwo porównawcze, współczesna poezja białoruska, literatura w kontekście społeczno-politycznym: postkolonializm, wielokulturowość, egzofonia.

Adres: Katedra Białorutenistyki Uniwersytetu Warszawskiego, ul. Szturmowa 4, 02-678 Warszawa, Polska.

Wybrane publikacje (2020-2021):

1. Эспіноса Руіс, Анхела. (2020). Літаратурна-міфалагічныя партрэты: героі і архетыпы ў народных і мастацкіх паданнях Беларусі ды Iсnаніi. „Acta Albaruthenica" 20: 87-94. 

